\title{
INTESTINAL MOTILITY AND TRANSIT FOLLOWING CHRONIC INGESTION OF DIFFERENT FORMS OF PALM OIL DIETS
}

\author{
A. O. OBEMBE*, O. O. OKWARI, D. U. OWU, A. B. ANTAI AND E. E. OSIM
}

\author{
Department of Physiology, College of Medical Sciences, University of Calabar, Calabar, Nigeria \\ E-mail: agonaobembe@yahoo.com
}

Summary: This study was aimed at finding the effect of palm oil diets on the small intestinal motor activity and transit in rats. Adult albino Wistar rats were divided into three groups of ten rats each. The first group was fed on rat chow containing $15 \%(\mathrm{wt} / \mathrm{wt}$ ) of fresh palm oil diets for fifteen weeks. The second was fed on rat chow containing $15 \%$ (wt/wt) thermally oxidized diet while the third group was the control and so was fed on rat chow only. Water and feed were allowed freely to all the groups. Intestinal motility and transit were measured after the feeding period. Results show that there was a significant increase $(\mathrm{P}<0.05)$ in basal tone of the ileum from rats fed on thermally oxidized palm oil diet when compared with fresh palm oil fed and control diets respectively. Contraction to acetylcholine $\left(10^{-11}-10^{-5} \mathrm{M}\right)$ showed a biphasic tone with highest contraction at lower doses of acetylcholine and lowest tone at $10^{-7} \mathrm{M}$ in both fresh palm oil-fed and thermally oxidized oil-fed groups when compared with control. There was a significant $(\mathrm{P}<0.05)$ attenuation of inhibition of atropine effect in the oxidized oil fed group when compared with control while there was a significant $(\mathrm{P}<0.01)$ increase in transit of food material in the intestine of oxidized oil-fed group when compared with control and fresh palm oil-fed groups. These results show that chronic ingestion of oxidized palm oil diet causes an increase in basal tone of ileum and enhances intestinal motility and transit in the rat.

Key words: Palm oil, intestinal motility, transit, atropine

\section{Introduction}

Palm oil from the fruits of Elaesis guineensis is the cheapest and commonly used oil in Nigeria. It is used either in its fresh or thermally oxidized (bleached) form. Thermally oxidized palm oil is different from the fresh because of the presence of free radicals released as a result of heating (Osim et al, 1994; Owu et al, 1998). The fresh palm oil, besides having saturated to unsaturated fatty acids close to unity, also contains vitamins A, E and carotenes which are antioxidants and scavengers of free radicals (Ghafourunissa, 1995).

Thermoxidation of palm oil has been reported to cause several impairments such as decrease in body weight and growth retardation (Isong, et al, 1997), depletion of vitamins A, E and carotenes (Ghafourunisssa, 1995; Kamat, 1997). There is mass destruction of the tissues and organs like the kidneys and liver (Osim et al, 1994), and blood vessels (Owu et al, 1997) are not spared. Lipid peroxidation leads to dysfunction of the cell membrane, decrease fluidity, inactivation of receptors and enzymes and changes in ion permeability, (Ozcelik et al, 2003). Due to tissue degeneration, there occurs the leakage of membrane electrolytes such as $\mathrm{Na}^{+}, \mathrm{K}^{+}$and $\mathrm{H}^{+}$thus resulting in the amplification of the electrical conductivity of the membrane (Alexander, 1979).

There seems to be a relationship between intestinal motor activity, transit and absorption of food though a previous study showed that a diet rich in palm oil did not adversely affect the transport of various food substrates in the small intestine (Abaelu et al, 1991). The red palm oil improves the healing of mucosal injury (Esterhaye et al, 2006) and this may be one of the reasons no adverse effects are seen in intestinal motility after the consumption of a fresh palm oil diet. However, repeatedly heated oil may be harmful because it causes oxidative damage thereby predisposing to atherosclerosis (Adam et al, 2008).

There is paucity of information regarding the influence of chronic feeding of different commonly consumed forms of palm oil on motility and transit in the small intestine. An early study showed that oxidative stress on rat small intestine induced a contraction followed by a slow relaxation and the response is probably intracellularly induced (Van der Vliet et al, 1990). The long chain (n-3) polyunsaturated fatty acids (PUFA) found especially in the peroxidized palm oil (D'aquino et al, 1991) have been found to modulate contractility of the small intestine (Patten et al, 2002). Since contractile events occurring within the intestine are under the control of the enteric nervous system as well as increment of appropriate electrolytes, it becomes expedient to verify if the oxidative damage on the small intestine (Rezk et al, 2003) and the electrolyte leakage reported after lipid peroxidation affect motility and transit of food in the small intestine.

\section{Materials and methods Palm oil diet}

Palm oil was purchased from a local market in Calabar and divided into 2 equal portions. The first portion remained in it fresh form and was certified fresh by virtue of its low oxidation value (Rossel, 1983). The other portion was thermally oxidized following the method reported previously (Osim et al, 1994). Briefly, the oil was heated intermittently at about $150^{\circ} \mathrm{C}$ in a stainless steel pot five times with each round of 
heating lasting about 20minutes. The oil was allowed to cool for 5 hrs before the next round of heating. The test meals Fresh palm oil, (FPO) and thermoxidized palm oil (TPO) were formulated by mixing $85 \mathrm{~g}$ of rat chow with either $15 \mathrm{~g}$ of fresh palm oil for (FPO) diet or $15 \mathrm{~g}$ of thermoxidized palm oil for TPO diet respectively. The two diets were stored in black containers at $-4^{\circ} \mathrm{C}$ to prevent further oxidation of the oil component. The control group was fed on only rat chow.

\section{Experimental animals}

Thirty Albino rats of Wistar strain were bred in the Department of Physiology, University of Calabar, Nigeria. The rats weighed between $55-$ $60 \mathrm{~g}$ at the start of the experiments and were about 60 days old. The rats in the first group were fed only rat chow (Control). The second group was fed on fresh palm oil diet while the third group was fed on thermoxidized palm oil meal. The stock diet was obtained from Pfizer Co. Nigeria Ltd. Lagos, Nigeria. All the rats had free access to tap water and were fed ad libitum for 15 weeks. They were housed in plastic cages in a room with $12 \mathrm{~h}$ light/dark cycle at room temperature of $27 \pm 2^{\circ} \mathrm{C}$.

\section{Intestinal transit}

Transit time was measured by a method modified by Uwagboe and Orimilikwe (1995). Rats in the three groups were deprived of food but allowed water for 24 hours before the experiment. Rat chow (50g) was ground, sieved and mixed with $200 \mathrm{ml}$ of water. The mixture was stirred for 30minutes. It settled into 3 layers namely, the topmost, middle and bottom layers. Both the topmost and the bottom layers were discarded. The middle layer was used because it is more homogenous and richer in nutrients.

An aqueous suspension $(95 \mathrm{ml})$ of $10 \%$ charcoal (BDH, England) was mixed with $5 \mathrm{ml}$ of $0.15 \%$ Leishman's stain (BDH, England). Twenty $\mathrm{ml}$ of the Leishman charcoal mixture was mixed with the middle layer of the chow. All the rats were fed orally with $3 \mathrm{ml}$ of Leishman's stain food mixture using $8 \mathrm{~cm}$ metallic incubating string. The experiment was timed for 90 minutes to allow time for food to move from the ileum completely. At the end of 90minutes, the rats were sacrificed by decapitation and the abdomen cut open immediately to expose the intestine. The location of the Leishman stain food mixture in the intestine was measured using a meter rule. The initial position of the dye nearest the pylorus was subtracted from the position of the marker nearest the caecum. The intestinal transit was calculated as length moved by marker/total length of the small intestine x 100 .
Motility

The animals were starved 24 hours prior to the start of the experiment to ensure complete emptying of the small intestine. The animals were sacrificed by stunning. An incision was made immediately on the shaven abdomen along the linea alba to expose the abdominal content. A length of $0.1 \mathrm{~m}$ from the jejunum and ileum was cut and placed in a Petri dish containing Tyrode's solution. The tissues were continuously aerated with an aerator (Charles Austins pumps, Sumy, U.K) to keep the tissue alive, care was taken not to stretch the tissues. The tissue bath was also aerated and maintained at $37{ }^{\circ} \mathrm{C}$.

\section{Experimental procedure}

The isolated tissue was cut to length of about $5 \mathrm{~cm}$ and thread attached to both ends of the tissue with a suture needle. The tissue was then mounted in the tissue bath of $50 \mathrm{ml}$ capacity. One end of the tissue was tied to the hook of the tissue bath and the other end to the writing lever of the kymograph. The tissue was bath with a Tyrode's solution and allowed to equilibrate after 45 minutes. The bathing solution was flushed out at intervals of 15 minutes and the kymograph drum set to rotate at a revolution of 0.01 revolutions per second. After equilibration, the basal response was obtained after which acetylcholine $\left(10^{-9}-10^{-3}\right)$ were added to the organ bath. After each reading the tissue was rinsed 3 times before administration of the next dose. Atropine $(0.2 \mu \mathrm{g} / \mathrm{ml})$ was also administered and its antagonistic effect recorded.

\section{Statistical analysis}

Data are presented as mean \pm standard error of mean. Analysis of variance was used followed by post hoc least square difference test where the comparisons were statistically significant. SPSS software version 10 was used for the analysis. The probability level of 0.05 was considered statistically significant.

\section{Results}

\section{Basal contraction}

The mean height of basal contraction of the ileum of rats fed on control and experimental diets is presented in Fig. 1. The mean basal contraction in the control group was $2.4 \pm 0.2 \mathrm{~mm}$ while that for FPO and TPO were $2.6 \pm 0.3 \mathrm{~mm}$ and $4.7 \pm 0.2 \mathrm{~mm}$ respectively. There was no significant difference between the mean contraction in the control and FPO groups. However, there was significant $(\mathrm{P}<0.01)$ increase in basal height of contraction in TPO group when compared with the control or FPO group respectively. 
Effect of graded doses of acetylcholine on ileal contraction

There was a biphasic response by the ileal smooth muscles to acetylcholine in the test groups when compared with control (Fig. 2). There was a dose-dependent decrease in contraction of ileum from both FPO and TPO when compared with control whereas there was a dose-dependent increase in contraction of the ileum from the control rats. The ileum from FPO and TPO groups had a minimum response at a dose of $\log \mathrm{M}$ of -6.7 after which there was an increase in contraction.

\section{Effect of atropine}

The application of a single dose of atropine produced a decrease in motility of the ileum from both control and test groups (Fig. 3). The percentage decrease in motility in control group was $340 \pm 15 \%$ in control, $350 \pm 10 \%$ in FPO and $135 \pm 15 \%$ in TPO groups. There was a significant $(\mathrm{P}<0.01)$ attenuated relaxation to atropine in TPO ileal smooth muscle when compared with control and FPO groups. The percentage decreases in relaxation response to atropine were comparable between the FPO group and control.

\section{Effect of palm oil diets on intestinal transit}

The intestinal transit for the control, FPO and TPO groups were $29.48 \pm 4.42 \%, 35.19 \pm 2.8 \%$ and $43.44 \pm 2.68 \%$ respectively. The intestinal transit was significantly $(\mathrm{P}<0.05)$ higher in the TPO group when compared with either control or FPO groups. However, there was no difference in transit level when the values between the control and FPO groups were compared (Fig. 4).

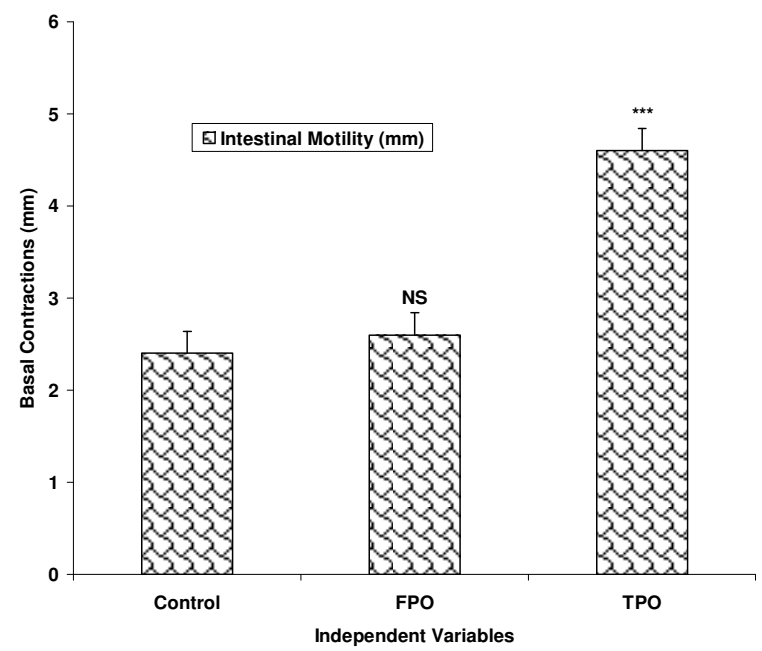

Fig. 1: Comparison of mean basal intestinal contractions in control, fresh and thermoxidized palm oil fed rats. $N=5$. $* * *=P<0.01$

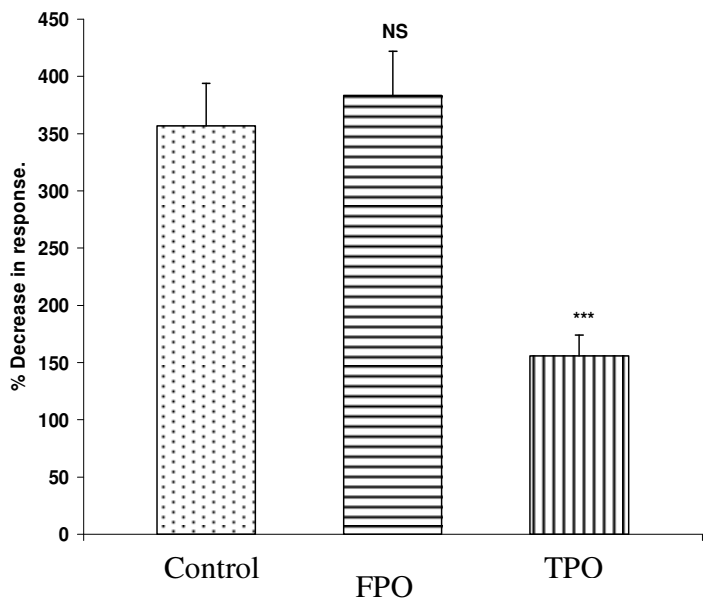

Fig. 3: Effect of atropine on intestinal motility in control, fresh and thermoxidized palm oil-fed rats. $N S=$ not significant, $* * *=P<0.001$

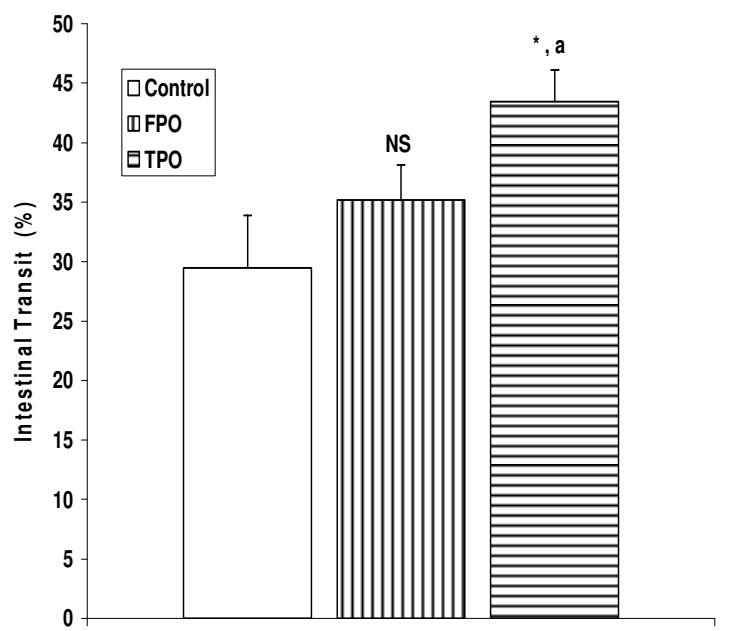

Fig. 4: Mean intestinal transit in rats fed on control, fresh palm oil and thermoxidized palm oil diets. $N=5, N S=$ not significant versus control, * $=P<0.05$ versus control, $a=$ not significant versus TPO 


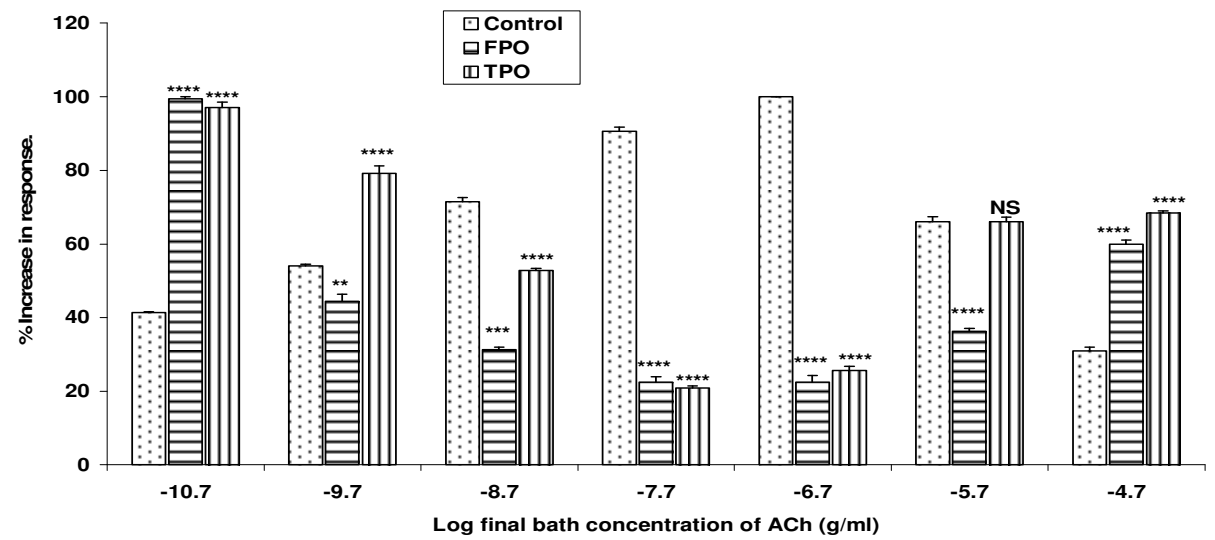

Fig. 2: Effect of graded doses of acetylcholine on intestinal motility in control, fresh and thermoxidized palm oil-fed rats. $* * *=P<0.001, N=5$

\section{Discussion}

Intestinal motility and transit following chronic ingestion of different forms of palm oil diets were studied. The chronic consumption of thermally oxidized oil led to increase in intestinal motility which may be due to the fact that thermally oxidized oil contains components that may induce oxidative stress. Disruption, erosion of the mucosal lining and general irritation of the intestine has been previously reported in intestine of rats fed on thermally oxidized palm oil diet (Igiri et al, 1994). This can therefore expose the muscle coat of the intestine to various vasoactive agents that can cause contraction. Tissue erosion and degeneration can cause leakage of electrolytes such as sodium, potassium and hydrogen ions into the muscle coat layer of the intestine leading to amplification of the electrical activity of the intestine (Alexander 1979). Since damage to cytoarchitecture of the small intestine results in the leakage of various ions, it invariably means that certain ion channels may be affected. Opening of calcium-sodium ion channels enhance calcium ion entry which causes contraction of smooth muscle cells (Guyton and Hall, 2006). It is likely that more calcium and sodium ion channels were opened in TPO fed rats than in FPO to cause more ion entry thereby resulting in exaggerating contraction. This may therefore be one of the contributory factors in the enhancement of basal intestinal motility in the TPO group when compared with control or FPO groups. In support of this finding, a study showed that oxidative stress on rat small intestine induced contractions followed by slow relaxation responses that were intracellularly induced (Van der Vliet et al, 1990).

Low doses of acetylcholine produced increase in amplitude of contraction whereas higher doses resulted in a reduction of contraction thus showing that the responses of the ileum from both FPO and TPO to acetylcholine were biphasic. The mechanism of this biphasic response is unknown. However, long chain polyunsaturated fatty acids (PUFA) present in palm oil have been found to modulate the contractility of the small intestine (Patten et al, 2002) and these are found in both forms of palm oil, though in different proportions (Okiy and Oke, 1986; Hassan, 1988). The decrease in contraction of the ileum at high doses could be attributed to the desensitization of receptors and enzymes. Ozcelik et al (2003) reported that apart from change in ion permeability associated with ingestion of peroxidized oil, there is also inactivation of receptors and enzymes. This may be the probable reason for the decrease in contraction at higher doses of acetylcholine in both FPO and TPO groups when compared with the control.

There was greater intestinal transit in the rats fed on TPO diets than in FPO and control diets group. This correlates positively with the increase in basal contraction in these groups. The greater transit in TPO reflects the increase in basal tone in the TPO group. In conclusion, chronic ingestion of thermally oxidized palm oil diet may lead to increased intestinal motility, transit and hypersensitivity to cholinergic agonist. It may therefore provoke or aggravate diarrhea if these results are applicable to man.

\section{References}

Abaelu, A. M., Okochi, V. I., Oyesile, O. O., Akinyele, J. O. and Akinrimisi, WE. O. (1991). Nigerian dietary oils and transport of amino acids in rats. Niger. J. Physiol. Sci. 7: $32-37$. 
Adam S. K, Soelaiman I. N, Umar N. A, Mokhtar N, Mohamed N, Jaarin K. (2008). Effects of repeatedly heated palm oil on serum lipid profile, lipid peroxidation and homocysteine levels in a post-menopausal rat model. Mcgill J Med. 11(2):145-151.

Alexander, J. C. (1979). Biological effects due to changes in fat heating. J. Am. Oil Chem. Soc. 55: $711-715$.

Esterhaye, J. S., Van Rooyen, J.,Strijdom, H., Bester, D. and Du Toit, E. F. (2006). Proposed mechanism for red palm oil induced cardioprotection in a model of hyperlipidaemia in the rat. Prost. Leuc. Essent. Fatty Acids. 18:

D’Agueno, M., Benedetti, P. C., Defelice, M., Gentili, V., tomassi, G., Maiorno, M. and Ulsini, F. (1991). Effect of fish oil and coconut oil on antioxidant defence system and lipid peroxidation. Free Rad. Res. Comm. 12: 147 - 152.

Ghafourunissa, K. (1995). Nutritional and health implications of palm oil. India J. Med. Res. 102: 233 - 234.

Guyton, A. C and Hall, J. (2006). Textbook of Medical Physiology. $11^{\text {th }}$ ed. Philadelphia, W. B. Saunders,

Hassan, A. H. (1988). Palm oil and health. The Planter. 5: 505 - 519.

Igiri, A. O., Ibegbu, A. O. and Osim, E. E. (1994). The morphological and histological changes in small intestine induced by chronic consumption of palm oil diets in rats. Tropical J. Applied. Sci. 3: $144-153$.

Isong, E. U., Ebong, P. E., Ifon, E. T., Umoh, I. B. and Eka, O. U. (1997). Thermoxidized palm oil induced reproductive toxicity in healthy and malnourished rats. Plant Foods Hum. Nutr. 15: 159 - 166.

Kamat, J. P., Sarma, H. D., Devasagayam, T. P., Nesaretnam, K. and Basiron, T. (1997). Tocotrienols from palm oil as effective inhibitors of protein oxidation and lipid peroxidation in rat liver microsomes. Mol. Cell. Biochem. 170: $131-137$.

Okiy, D. A. and Oke, D. L. (1986). Nutritional evaluation of thermally deteriorated palm oil. Oleagineux. 41: $77-81$.
Osim, E. E., Owu, D. U., Isong, E. U. and Umoh, I. B. (1994). Influence of chronic consumption of thermoxidized and fresh palm oil diets on basal metabolic rate, body weight and morphology of tissues in rats. Discovery and Innovation. 6: 389 - 396.

Owu, D. U., Orie, N. N. and Osim, E. E. (1997). Altered responses of isolated aortic smooth muscles following chronic ingestion of palm oil diets in rats. Afr. J. Med. Med. Sci. 26: 83 - 86.

Owu, D. U., Osim, E. E. and Ebong, P. E. (1998). Serum liver enzymes profile of Wistar rats following chronic consumption of fresh or thermoxidized palm oil diets. Acta Tropica. 69: 65 - 73.

Ozcelik, D., Ozara, S. r., Gurel, Z., Uzun, H. and Aydin, S. (2003). Copper mediated oxidative stress in rat liver. Biol. Trace Elements Res. 96: 209 - 215.

Patten, G. S., Abeywardena, M., McMurchi, E. J. and Jahangi, A. (2002). Dietary fish oil increases acetylcholine and eicosanoid induced contractility of isolated rat ileum. Am. Soc. Nutr. Sci. 132: 2506 - 2513.

Rezk, B. M., Haenen, G. R., van der Vijgh, W. J and Bast, A. (2003). Tetrahydrofolate and 5-methyltetrahydrofolate are folates with high antioxidant activity. Identification of the antioxidant pharmacophores. Febs. Letters. 555: $601-605$.

Rossel, J. B. (1983). Measurement of rancidity. In: Allen, J. C. and Hamilton, R. J. (eds.) Rancidity in Food. London, Applied Sci. Publishers. pp 21- 46.

Uwagboe, P. E. and Orimilikwe, S. O. (1995). Effect of histamine $\mathrm{H} 2$ blockers on gastric intestinal tract in the conscious Albino rats. Niger. J. Physiol. Sci. 11: 56 - 58.

Van der Vliet, A., Tuinstra, T. J., Rademaker, B. and Bast, A. (1990). Intestinal motility disorder induced by peroxides: Possible role of lipid peroxidation. Res. Chem. Pathol. Pharmacol.70: 227 - 243. 